\title{
"Written barracks" \\ On the Production and Circulation of Newsletters in the Internment Camps of Southwest France
}

\author{
Guadalupe Adámez Castro \\ University of Alcalá/SIECE-LEA, Alcalá de Henares, Madrid
}

\section{ABSTRACT IN ENGLISH}

Around half a million Spanish exiles crossed the French border in the Pyrenees between January and February of 1939. They were looking for shelter in anticipation of the overthrow of the Spanish Second Republic. The reception of the exiles in France was rather hostile, and approximately a quarter of a million of them were locked up in internment or concentration camps that French authorities improvised or reactivated camps of WWI. The exiles were defeated and they were deprived of freedom and forced to live in insalubrious conditions. The refugees used writing and culture as a strategy to resist, and as a means to hang on to their personal, familial, social and ideological identities. As a result of their cultural activity, a wide range of newsletters and diaries were edited in the internment camps despite the scarcity of resources. The refugees used these writings as a means of entertainment but also to spread their own doctrines. This article analyzes some 30 newsletters produced by a variety of groups in the camps: political groups, which were mostly linked to the field of education, different intellectuals and members of the International Brigades. The main goal of this work is to disentangle how the newsletters were produced, discuss the aims of the different publications and show how the texts were circulated and exchanged within the internment camps. Ultimately, the purpose of this work is to demonstrate the meaning of these communications for their authors and their readers and examine how the texts were used to reconstruct their lost identity. 


\section{RESUMEN EN ESPAÑOL}

Entre enero y febrero de 1939 alrededor de medio millón de españoles cruzó la frontera con Francia en busca de refugio ante la inminente derrota de la República. La acogida que tuvieron en el país galo no fue ejemplar, aproximadamente 250.000 fueron recluidos en campos de internamiento o de concentración improvisados y reutilizados de la I Guerra Mundial. Convertidos en refugiados, derrotados, privados de libertad y viviendo en unas condiciones insalubres, todos ellos se sirvieron de la escritura y de la cultura como una estrategia de resistencia, como armas para aferrarse a su identidad personal, familiar, social e ideológica.

Fruto de esta actividad cultural son los distintos diarios y boletines que, a pesar de la escasez material, se editaron dentro de los propios campos y que los refugiados emplearon como medios de circulación de noticias, como forma de entretenimiento y como vehículos de adoctrinamiento. El propósito de este artículo es analizar una treintena boletines producidos por diversos grupos: políticos, vinculados al mundo de la enseñanza, intelectuales, brigadistas, etc. Mi objetivo es desentrañar cómo fue la producción de dichos boletines, qué finalidad tuvo su publicación y cómo fue su circulación y difusión de los mismos dentro de los propios campos. De esta forma, quiero analizar qué significado tuvieron tanto para sus autores como para sus lectores y cómo fueron usados para reconstruir su identidad perdida.

Keywords: Spanish exile, internment camp, written culture, handwritten press

\section{INTRODUCTION}

\section{WHAT'S HIDDEN INSIDE THE SMARTPHONE OF A REFUGEE?}

The above question is the opening trigger for the film documentary District Zero (Pablo Iraburu; Jorge Fernández; Pablo Tosco, 2015). In the documentary, the authors portray the daily life of nearly 81,000 Syrian refugees currently confined in the refugee complex of Zaatari, Jordan (UNHCR, 2015). The narration does not pretend to merely bring to light the drama of these exiles and their uncertain destiny but, rather, "District Zero" delves into the daily life of the refugees, and investigates their main concerns, such as how they use their resources to maintain a connection with their own past and consequently, how they are able to anticipate their future. Maamun Al-Wadi, a young Syrian refugee who arrived with his family at Zaatari after fleeing from the war, is the leading figure of the documentary. Al-Wadi runs a small store that repairs cell phones and smartphones for fellow countrymen and refugees in the camp, and 
thanks to Al-Wadi's little business, the refugees are able to have an open window into the world that seems to be vanishing from them.

Thousands of Spaniards shared the same destiny as the present Syrian refugees, although in another country and in another context, but also in the aftermath of war. It was 79 years ago. Those Spaniards were also forced to develop means of communication with the world outside their internment camps. In their case, the Spaniards were fleeing before the impending overthrow of the democratic Second Republic in Spain. Between January and February of 1939, the defeat of the Spanish Republic was imminent, and thousands of people fled from the hunger, air raids, and social and political reprisals in their fatherland. The most intense episode of exile began after the occupation of Barcelona by the rebels of Franco's Army in January of 1939, which clustered together some half a million Spaniards looking for aid and assistance along the French border of the Pyrenees.

Many of those who struggled to run away had never been political nor military leaders, but they were led by the fear of reprisal. It was the horror of "everyone for himself", as the historian Antony Beevor puts it." The journey to the Pyrenees and the arrival at the French frontier were commonly portrayed by Spanish exiles in their diaries and memories. One of those testimonies was written by Silvia Mistral, with the pen name of Hortensia Blanch Pita, who retold among other episodes the way in which her family managed to run away on February 4th 1939:

Caravans of men, women and children. Of scattered soldiers and fugitive farmers. You could hardly hear people talking and if so only to complain about their fatigue or to cheer their fellows up in order to support a walk that seemed never-ending. Our pupils get exhausted, and even our souls because of this overwhelming vision of exodus, of looking ahead toward new horizons. A soldier said he participated in the military retreats of Bilbao, Santander, Gijon and the one by river Ebro among many others. This latter one was perhaps, no need to say it, the last one. That is the reason why somebody said that "the Spanish soldiers are "espadrille soldiers".. ${ }^{2}$

Within the half million Spanish refugees who crossed the French Border, the official estimate calculates that a quarter of a million, mostly male, citizens were imprisoned in concentration or internment camps. ${ }^{3}$ There were thousands of men who after three years of war in Spain (1936-1939) found themselves confined in wire-fenced beaches on the French coast: Saint-Cyprien, Barcarès, Argelès-sur-Mer, Gurs, Agde and Rivesaltes are some of the names of the camps in the French metropolis, notwithstanding the existence of some other camps in the French colonies of Northern Africa. In fact, the last flood of Spanish refugees would arrive in the French territories in Northern Africa after the final defeat of the Spanish 
Republic. These figures were reduced in the following years due to different measures ordered by the government of the French Republic. In particular, repatriation to Spain and re-emigration to third countries were the two most influential measures for the refugees. The French authorities exercised pressure upon the exiles in an attempt to urge the Spanish refugees back to their own country, whereas re-immigration was the most desired-although certainly the most difficult to obtain-alternative for the refugees in French territory. ${ }^{4}$ One of the paths that led Spanish refugees out of the camps was through employment that could be done in two ways: finding a job contract outside the concentration camp or joining one of the Compagnies de Travailleurs Étrangers (Companies of Foreign Workers) created by the French government in spring 1939, enlistment in which was voluntary at the beginning but become mandatory after September 1939 due to the lack of workforce during Second World War. ${ }^{5}$ And the last of the measures was precisely to fight together with France in this War.

This conflict had a great influence on the daily life inside the camps, especially on their population and their control. In the last months of 1939, the camps began to empty of Spanish refugees and filled up with new prisoners, while their control was taken over first by the Vichy regime and afterwards by the Nazis. We can find one paradigmatic example in the camp of Argelès-sur-Mer, where many different communities lived together: Spanish refugees, International Brigades members, gypsies, foreigners living in France-mostly antifascist Germans and Italians-, and Jews. ${ }^{6}$ Argelès was one of the "accommodation camps" where Vichy government interned "undesirable foreigners", but there were also punishment camps like Le Vernet, transition camps like Les Milles and other precursors to extermination camps like Drancy, ruled by the Nazis from 1943. ${ }^{7}$ By that time, most of the Spanish refugees had left the camps due to the measures explained before, with the result that, according to the official registers, only 4,327 Spaniards remained imprisoned in January $1942 .{ }^{8}$

\section{INTO THE CAMPS}

The insalubrious conditions of the camps were certainly extreme. During the first days of confinement, the lack of barracks for shelter meant days and nights of survival outdoors for the prisoners, while a supply of water which came directly from the sea provoked several diseases among the refugees. The food supply was also completely insufficient, ${ }^{9}$ sometimes just a loaf of bread and, on the best days, some canned food. Because of these harsh conditions, the number of deaths during the first months was 
so high that some of the refugees considered the camps to be "beaches of death". ${ }^{10}$ Some others wrote deep reflections in which the camps were represented as cemeteries. In the following fragment of his memories written during his internment and published in Venezuela in 1940, Jaime Espinar describes the camp of Argelès-sur-Mer in these terms:

The camp was not even a "camp" of which one could expect some kind of foresight and organization. It was a spot on the Mediterranean shore, a stark place where the February winds gathered to shake their whips against our Spanish skin. Any place on Earth serves as a cemetery. A beach or a mountain. Near or distant to the clouds, it is just the same. The French government tries to channel the overflowing river of emigration near the seashore. Once arrived to Argelès, one looks through the village and says: "Here!". And here is the levee. The river began to calm down until it became a lake made out of blood. ${ }^{11}$

It was in those sandy areas of France, completely defeated, deprived of the most fundamental liberties, and stripped of their own identity, that the refugees were forced to construct a whole new world, to "become men again", as stated in one of the verses written by Narcís Molins i Fabrega, one of the refugees, in his Mexican exile. ${ }^{12}$ Political associations, unions and institutions still linked to the cause of the defeated Republic encouraged the refugees to fight and resist, to organize and to use culture and writing as indispensable weapons for their cause and the construction of their new identity: an identity as refugees, who had to survive as captives, far from their country, their family, their culture. They had to survive in a geographical and social space very different from the one they had had until that moment. ${ }^{13}$ In order to face those conditions, the refugees used pencil and paper as a way to resist the situation and provide entertainment for themselves as has been done in other contexts of confinement and repression, such as the Warsaw ghetto, WWII concentration camps, and Spanish prisons during Franco's dictatorship. ${ }^{14}$ This fact is explained, in some way, by the relationship between traumatic episodes and the use of writing, especially in the contemporary age, when more people had access to literacy. As Armando Petrucci has stated, the events that occurred during the $20^{\text {th }}$ century led individuals not only to write about something, but to write themselves. ${ }^{15}$

\section{WRITING TO SURVIVE}

The writings during the internment were certainly diverse, and they were a result of the most urgent necessities of the refugees. The most important 
typology, though this is not the main scope of this article, was epistolary writing, both the penning and reception of letters. Most of these missives were addressed to relatives or friends and had to overcome several difficulties, such as launching a postal system in order to allow for sending and receiving letters, obtaining stamps, navigating the censorship imposed by the French authorities, and finding relatives and friends outside of the camps in France (or finding the addresses of relatives in Spain whose addresses had changed because of the war and the continuous flux of population). ${ }^{16}$ Nevertheless, and thanks to the resolution of the refugees and the help of some aid agencies for refugees, epistolary exchange with friends and relatives became possible. We know this from the 80,000 messages that were sent from the internment camps between April $15^{\text {th }}$ and June $15^{\text {th }} 1939$ through the Service of News to Relatives launched by the International Committee of the Red Cross. ${ }^{17}$

In addition to the letters sent to relatives and friends, letter of request and petitions also had special relevance. The refugees sent petitions to different aid organizations, some supported by the defeated government of the Second Republic, with the hope of having a response to their demands. With the help of these organizations, they intended to leave the internment camps and have tickets for the ships that transported thousands of exiles to other host countries, such as Mexico or Chile. ${ }^{18}$ Initially, the great number of letters provoked a collapse in the offices of the aid agencies. In the following excerpt, Amaro del Rosal describes the situation in the offices that the General Union of Workers (or Union General de Trabajadores, UGT in Spanish) opened in Paris in order to help its members in the camps and operate as an intermediary with the Servicio de Evacuación de los Republicanos Españoles (SERE), an official agency supported by the Republican Government in exile:

The offices of the Executive Commission received up to two hundred letters per day. As soon as the SERE started to operate, the requests addressed to the UGT counsellor, A. del Rosal, maintained the same frequency and number of requests, so we were obliged to set up a whole group of typists only to respond to the correspondence [...]. From that moment on, the case and petition of each refugee problem was treated individually. ${ }^{19}$

We cannot forget other typologies of intimate writings, such as personal diaries. In them the exiles were able to leave a record of their daily life, put their most profound reflections into words and let their darkest fears come out. Some authors think that these diaries served as a type of therapy, as a way to maintain the hope of the refugees. ${ }^{20}$ These diaries were used by many refugees as a therapy, as an introspective exercise, but were also important as testimonies. Many refugees wrote their biographies in order 
to leave a register of what was happening, of the injustice they were living. In this sense, for example, these are the words of the beginning of Elisa Reverter's dairy, written in the refugee camps of Couizà-Montazels (Aude):

Now, when I am imprisoned in a concentration camp for women in France completely in solitary confinement and isolated from the outer world [...], when I want to leave testimony of all the humiliation [...] and lack of hope that I feel and about the hard conditions of the life of exile. ${ }^{21}$

\section{WRITING TO FIGHT}

The intimate writings had no other addressee than their author, in case of diaries, or the addressee of each letter. However, there were also other penned products whose main potential recipients were the rest of the inhabitants in the camps. These writings were born to be seen, to circulate, and to be commented on. Within this typology, handwritten newspapers and handcrafted newsletters were the most important productions. In these writings, the refugees expressed and narrated their particular universe within the internment camp and learned about life outside of their camps. Thanks to those newsletters, the refugees were able to share their concerns and most intimate reflections. The newsletters are precisely the focus of this work whose main aim is to delve into the characteristics and the intentions of the pages of these writings, with a particular emphasis in the distribution and reception of the texts.

\section{WHERE AND HOW DID IT HAPPEN?}

The present analysis has investigated a corpus of more than thirty newsletters that were written within the internment camps between April $2^{\text {nd }}$ and November $30^{\text {th }} 1939$, the moment when a larger number of Spanish refugees were being held in the camps, and therefore, there was a greater cultural activity. Some of the newsletters have been edited and published and some others are preserved in different archives, mainly in the archive "Amaro del Rosal" of the Fundación Pablo Iglesias (AARD-FPI) in the city of Alcalá de Henares (Madrid), and in the Historical Archive of the same foundation, as well as in the archive of the Comintern in Moscow, Russia. I have accessed a copy of the Russian archive that is available at the Abraham Lincoln Brigade Archive (ALBA) in New York City, USA (Table 1).

Given their short life, their short print run, the bad quality of paper, and the lack of interest of the authorities in their conservation (both by the personnel in charge of the French camps and the organizations 


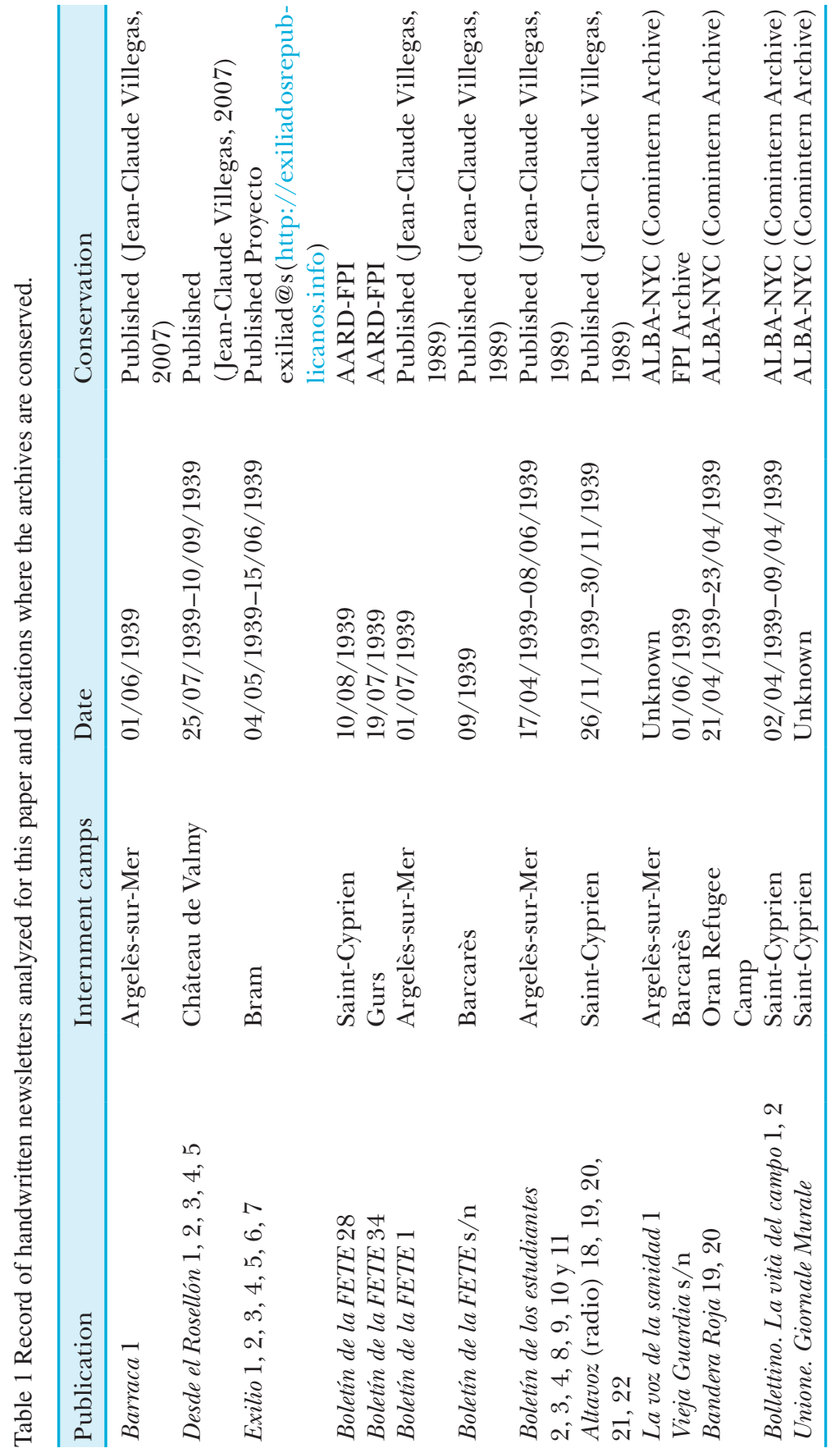


behind their production), very few examples of these newsletters and newspapers remain nowadays, despite the fact that these writings were quite widespread inside the camps. Consequently, the location and identification of the documents entail an arduous work of research. In many cases, the preservation and recovery of the materials depended on private owners who were in some way related to the creation and history of the texts and who later decided to preserve some samples of them..$^{22}$ The overall preservation of the texts has depended on unions, political parties and aid agencies, which were the addressees of these newsletters in the past, providing proof of the educational and cultural activity within the internment camps.

This cultural activity normally took place within the barracks of the internment camps called "barracks of culture" which were allocated for hosting educational and cultural events and which were used more and more frequently. ${ }^{23}$ Luckily, some reports of this cultural and educational activity have been conserved, providing us with an idea of everyday life inside the camps. For example, the report written by Amparo Ruiz, a member of Federación Española de Trabajadores de la Enseñanza (FETE) on July $8^{\text {th }} 1939$, stated that there were 108 teachers and 4,048 pupils attending classes in the camp of Saint-Cyprien, mainly on the topics of French language and General World Culture. The report also remarked that some similar practices were held in camps like Agde, Barcarès, Septfonds, Montolieu, etc. ${ }^{24}$ By the same token, refugees could also participate in sports, musical and artistic activities inside the camps, demonstrating that the internment camps operated as small cities with a variety of spaces to spend some free time. However, these spaces were always very limited and were of course constantly guarded by the authorities.

The publication of newsletters became an important part of cultural activities and served as a testimony and reflection about life in the camps. Therein, some of the refugees narrated the way in which they edited and produced some of the newsletters, among the organization of other cultural activities. By a way of example, Adela Carreras Taura, also known as "Adelita del Campo", was one of the women interned in the camp of Argelès-sur-Mer. "Adelita del Campo" offers an excellent description of the production of the Boletin de los estudiantes (the Students' Bulletin) in the camp of Argelès. This newsletter was primarily produced by members of the Federación Universitaria Española (FUE). These are the words of "Adelita del Campo":

Just another day... Just as every other day, I walk towards [...] the barrack where FUE has its work room. I arrive. I go in. It's crowded. The board is so full you cannot put up anything more. Coloured pencils, blank paper, newspapers, tracing paper, cigarette butts, folders [...]. All the boys are 
working. Long live the work! Placed in line at both sides of the table, they lean their heads above the "Information" sheet of the newsletter, giving it colour, giving it light $[\ldots] .^{25}$

This testimony and the characteristics of other materials that I have accessed demonstrate that the production of newsletters was completely handcrafted. Sometimes the materials consisted of typewritten texts, with different font types and sizes for each section and the headlines. They also included elaborate illustrations along with the texts. Illustration techniques used by the refugees included simple ones, such as drawings made with coloured pencils or charcoal, as well as more stylized illustrations handcrafted with the use of watercolour. These last drawings sometimes included references to iconic images which had already been used in the war press that were fairly well known by the refugees. ${ }^{26}$

The length of the newsletter ranged from 2 pages for the humblest publications to around 45 pages for the most ambitious issues. The number of copies for each publication would also vary depending on the capacities of the editors, ranging from two copies of the review Exilio which was edited by the intellectuals in the internment camp of Bram, or twenty-five copies that the Boletin de los Profesionales de la Enseñanza produced for publication at the camp of Gurs. The ample reach of this latter bulletin and the fact that all of the copies were manually crafted proves the capacity for organization of the Federación Española de Trabajadores de la Enseñanza (FETE) in Gurs.

Among the different productions that I have studied it is also worth emphasizing the production of newspapers specifically designed and edited to cover the walls of the barracks, as well as the texts and posters that covered the "posts" used in the camp for publicity. The use of these posts of the camps by refugees to display their newspapers really means a spontaneous and unlicensed appropriation of the common spaces of the camps for their own benefit and according to their interests. An outstanding example of the latter type of publication was the Giornale Murale, Unione, a newsletter edited by the Italian members of the International Brigades confined in the camp of Saint-Cyprien. I will touch upon this again later in this paper.

\section{WHY AND FOR WHAT PURPOSE?}

Given the ideological nature and the propaganda purpose of some of these writings we can divide the texts in four main groups. First, we have intellectual texts such as Barraca (Argelès-sur-Mer) and Exilio (Bram). In this group, we mainly find literary texts with poetry and intimate reflections about experiences of alienation from the fatherland. These publications included carefully edited issues with a rich variety of illustrations. 
Secondly, we have the newsletters that were edited by professional groups. The most important publications within this type were the aforementioned FETE and FUE, and in particular the Boletin de los Profesionales de la Enseñanza (in Barcarès, Gurs, Argelès-sur-Mer, Saint-Cyprien) (Figure 1A and B) and the Boletín de los Estudiantes (Argelès-sur-Mer). These publications had the highest number of copies and the broadest circulation. The writers narrated their activities in the camp and in that way the newsletters became fundamental elements of remembrance and propaganda. The newsletter Altavoz even had a daily radio version in Saint-Cyprien. ${ }^{27}$ We can also find practical information about the daily life in the camps included in the newsletters. In addition, it is necessary to mention here a recent discovery, the newsletter La voz de la Sanidad was a professional text edited by the health staff at the camp of Argelès-sur-Mer. This newsletter included practical information about health, statistics and news. Within these first two groups of newsletters we can also find articles about the Spanish Civil War, the Spanish Republic, the Soviet Union, and Mexico.

Next we have the newsletters of political parties, such as the Vieja Guardia, which was edited in Barcarès by the socialists (Figure 2), or Bandera

\section{A}

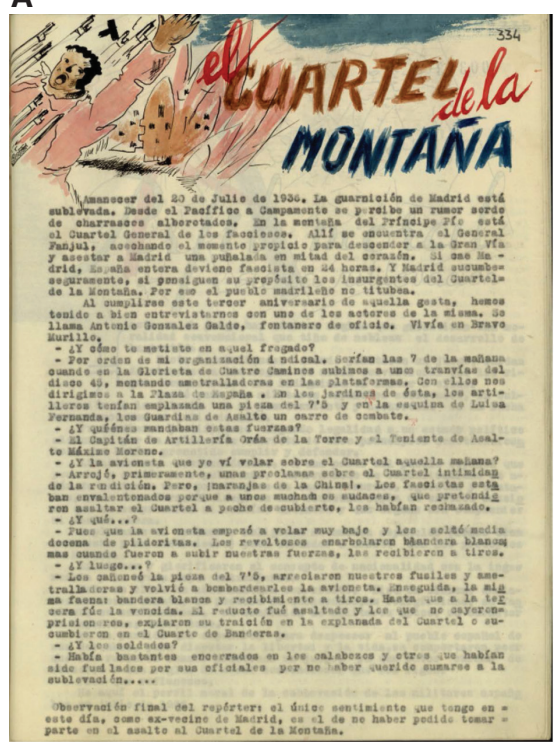

B

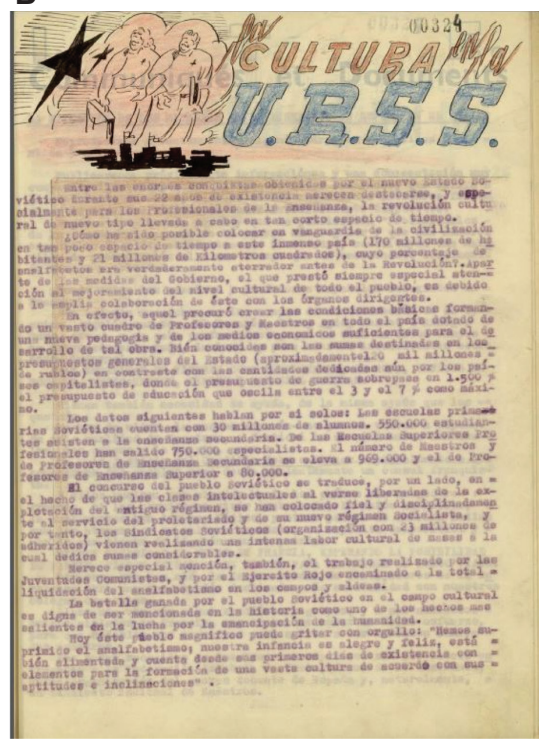

Figure 1 (A) Sample of newsletter produced by FETE, $n^{\circ} 34$ (Gurs). Source: AARDFPI, 270/2. (B) Sample of newsletter produced by FETE, $n^{\circ} 28$ (Saint-Cyprien). Source: AARD-FPI, 270/2. 


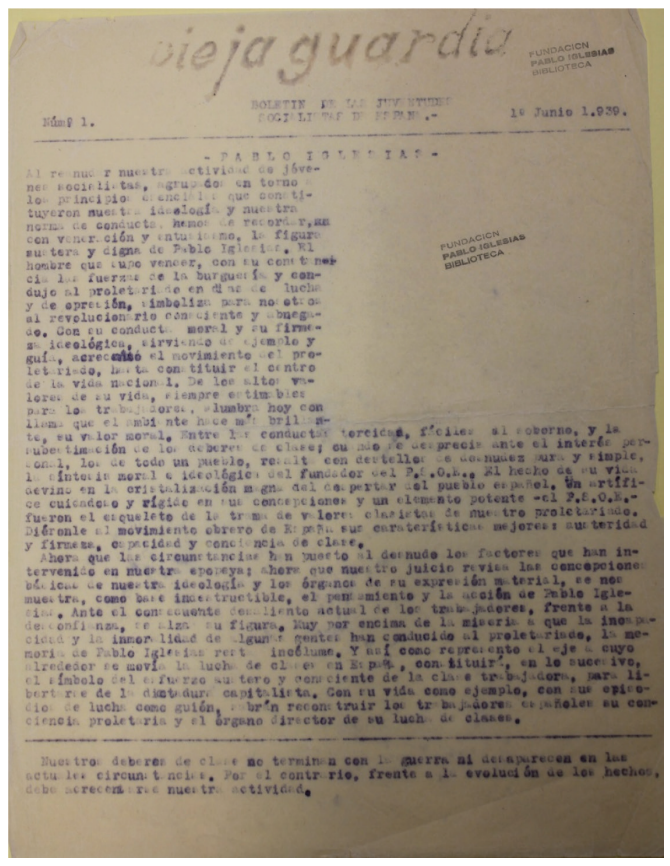

Figure 2 Sample of newsletter produced by Juventudes Socialistas de España, Vieja Guardia Boletín de las Juventudes Socialistas de España (Barcarès). Source: FPI Archive-169/8.

Roja, which was published in an improvised camp in Oran, Algeria, by communist militants. In this type of newsletter, we mainly find news and warnings regarding the inner functioning of the political party, as well as information related to the party, WWII, or biographical sketches of political leaders. The main goals of these newsletters were to inform and provide some guidelines for the members of the associations behind them, as well as to promote different texts with highly political content. This prioritization of the political content put the literary and artistic component of these publications in second place. These newsletters were of worse quality than other clandestine publications since their circulation was prohibited by the French authorities (because of their political character). The format and content of these works were similar to those of other clandestine publications of the time, such as the newsletters and other writings published in the prisons or camps in Spain during the Civil War and the post-War period after 1939, studied by Verónica Sierra Blas among others. ${ }^{28}$ 
Finally, we have the bulletins that were published by members of the International Brigades imprisoned in concentrations camps. Although the official withdrawal of the International Brigades took place in October of 1938, many of the volunteers, who were afraid of a possible reprisal in their homeland, decided to stay in Spain, mostly around the city of Barcelona. When this city fell, they had to flee with thousands of Spaniards to France, where they were imprisoned in concentration camps. The new refugees then faced a dramatic situation since they could neither receive help from the aid agencies supported by the Government of the defeated Second Republic nor be sent back to their home countries, which were in most cases under totalitarian regimes. The vicissitudes of these former members of International Brigades inside the camps have not been widely studied yet, but some empirical evidence shows that their daily life was not different from that of the rest of the refugees. Thus, like their fellow Spanish inmates, they also published newsletters and handwritten newspapers. I have accessed bulletins made by groups of Cubans, FrenchMoroccans, South Americans, as well as Italians who wrote in their native language. ${ }^{29}$

The most reliable information about this group is the research on the bulletin La vità del campo, which was edited and published by Italian members of the Brigades in Saint-Cyprien, and the mural newspaper

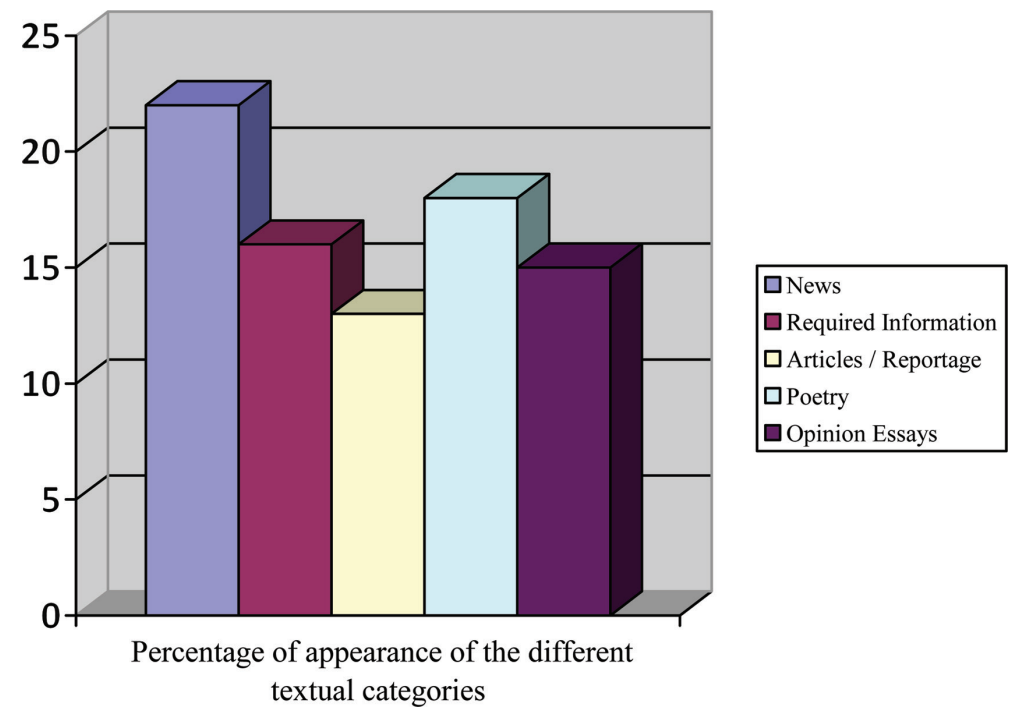

Figure 3 Representation of the different text genres appearing in the newspapers. 
named Unione. Both publications focused primarily on news and updates about WWII. We can also find, as shown in one of the sections of Unione, some practical information and instructions about how to get out of the camps. $^{30}$

All in all, the bulletins offered warnings, propaganda, and news, but also intimate reflections about exile, about the estrangement of living abroad under such circumstances and the lack of opportunities in their native countries. As we have seen before, these newsletters also contained topics of interest for everybody, such as reports about possible host countries (mainly Mexico and the USSR), or reviews about crucial moments of the Spanish Civil War (which made them remember their greatest feats and victories). Some of the publications also included veiled criticism about the hard conditions inside the camps and the aid organizations supported by the Republican government, sometimes using humour, as can be found in other examples of press produced in situations of coercion and imprisonment (Figure 3). ${ }^{31}$

\section{HOW WERE THE PUBLICATIONS CIRCULATED AND HOW WERE THEY RECEIVED?}

I cannot conclude this article without addressing the methods of distribution and circulation of the newsletters within the internment camps and also outside the camps. As a general rule, the newsletters were read by the refugees of the camp in which the newsletters were created. However, in some cases the publications reached a broader audience. For instance, Desde el Rosellón, which was the continuation of the newsletter Barraca in the camp of Argelès-sur-Mer, is a paradigmatic example of a broader circulation. Desde el Rosellón, due to its particular characteristics and conditions of publication, was distributed among the intellectuals of the area outside the camp. ${ }^{32}$

In addition to these examples, it is important to investigate how these newspapers were distributed within the internment camps, so that we can understand the real goals of these writings and their reception by readers. The distribution of the newsletters mostly depended upon the number of copies of each issue and the material of the publication. Obviously, the bulletins that published twenty or twenty-five copies had a broader circulation, and in certain cases made it possible that the refugees had access to texts from other internment camps. This was mostly the case for periodicals and information sheets edited and published in the field of education. For instance, the first issue of the Boletin de los Profesionales de la Enseñanza, which was published in the camp of Argelès-sur-Mer, defended the continuation of the work that their partners of the FETE were developing in Saint-Cyprien: 
Saint-Cyprien means for us work, organization, and the desire to continue a task that makes us, Spaniards and professional teachers, be honoured in the eyes of the world. The newsletters arrive, and they are a brief summary of what we have discussed earlier. They move us to send you a warm and affectionate greeting of encouragement and congratulations. We are eager to follow the route created by you. ${ }^{33}$

Unlike the bulletins with a broader distribution, the most modest publications were circulated within the camp by the refugees, who passed copies along to each other for purposes of personal reading. This was the case of the weekly publication named Exilio:

To our readers: Because of the length of the preparation of these handmade weekly publications and the difficulties of their distribution, we are only making two copies per issue. In order to spread our message, it is necessary that we all circulate it. Therefore, we ask everybody who reads a copy to give it back to its lender. This way we will be able to avoid its loss. ${ }^{34}$

In many occasions, the bulletins-and some external publications that were accepted through censorship in the camps-were distributed and read out loud in front of groups of refugees inside the barracks. As a matter of fact, Arturo Morera, a refugee, shared his memories of assigned "readers" in each internment camp. These "readers" were in charge of reading-and translating when needed-the periodicals and publications to his fellow inmates. ${ }^{35}$

The exposition of the texts operated as another means of circulation, and this was the case for both internal and external publications in the camps-such as the aforementioned Unione. The refugees used to cut and store some clippings, especially those related to disappeared relatives that were published in the local French press. The "posts for news" in the camps were also collages of clippings from diverse publications, and those posts became meeting points for the refugee reading groups. Lluís Ferrán de Pol, a prisoner in Barcarès, retold in his memoirs that those posts of news were the "morning newspaper" for the refugees. ${ }^{36}$ Another refugee, Luis Bonet López, crafted his own testimony by drawing a mural journal that was probably exhibited in the camp of Saint-Cyprien. This demonstrates that reading groups were part of the daily routine for the prisoners, as also Claude Laharie reminded us regarding the camp of Gurs. In Gurs, the board with the news was located next to the latrines in section $\mathrm{H}$, and often there was news or periodicals about commemorations and anniversaries. ${ }^{37}$

The circulation and reading of these bulletins both inside and outside the camps contributed to the spreading of news, although the news 
was always insufficient for the refugees due to the censorship. The consequences of the circulation were, however, broader than that.

The gathering of refugees for reading groups and discussion of the content of the texts contributed to the reorganization of the refugees, which also helped to ease some disagreements created among the different ideological groups during the last years of the Spanish Civil War. The refugees created a collective imagery of their exile that reshaped their identity around concepts and myths that were later transmitted by other refugees, such as the idealization of the Second Republic, especially of its educational policies and cultural initiatives which were the subject in some articles and reportage (Figure 4A and B); some episodes of the Civil War: Battle of the Ebro, the defence of Madrid, the participation of the International Brigade, etc.; the memory of Spanish culture: its poets, its costumes, its regions; as well as the positive image of the countries that received refugees and their authorities, especially Mexican president, Lazaro Cardenas.

A

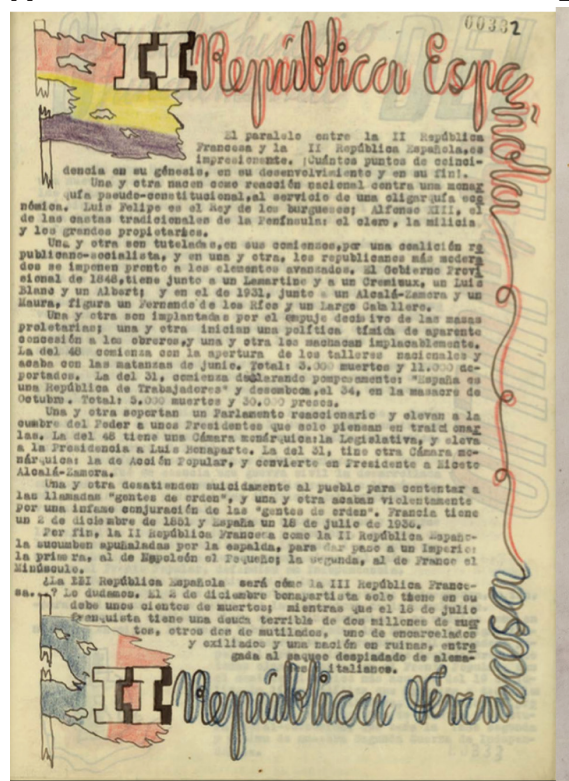

B

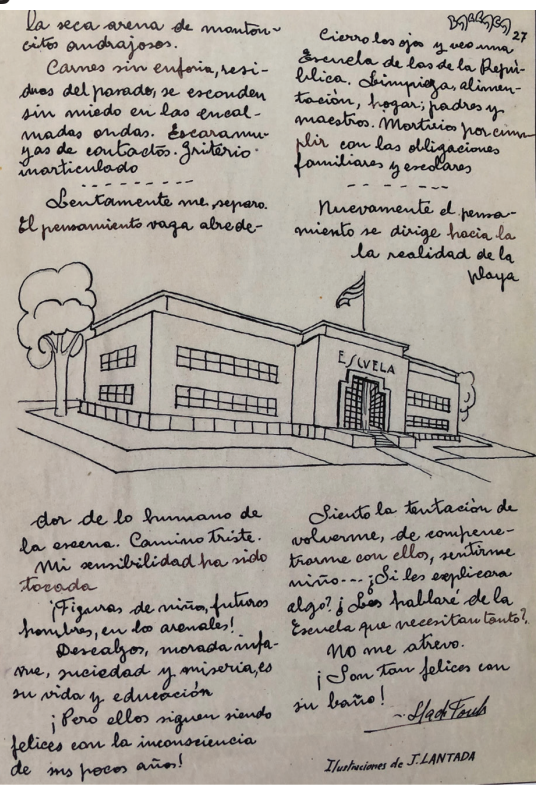

Figure 4 (A) Reportage about the Second Spanish Republic and Second French Republic in a newsletter produced by FETE, $\mathrm{n}^{\circ} 34$ (Gurs). Source: AARD-FPI 270/2. (B) Extract from a poem entitled Happiness in which they talk about the Spanish Republican school in a newsletter produced by a group of intellectuals, Barraca, $\mathrm{n}^{\circ} 1$ (Argelès-sur-Mer). Source: Reproduced in J.C. Villegas, 2007, p. 73. 
These topics turned out to be myths for the refugees, who used them to shape their new identities. The circulation of these publications and the sharing of the readings created real "reading communities", following the concept enunciated by Roger Chartier, in which these ideas were disseminated. ${ }^{38}$ These groups played a key role in the proliferation of the foundational myths as well as in the development of discourses on resistance that were part of the publications. Some of these cited topics, present in the edited newsletters, were re-used during the Mexican exile, based on common and recurrent imaginaries, according to Jorge de Hoyos. ${ }^{39}$

Finally, the bulletins, and in particular the murals, had another function - the elaboration and exposition of works by the refugees in a hostile atmosphere was a way for their ideas, their culture and, in some respects, their past to be present in daily life of all the inmates (Figure 5). In a sense, to show the power of the authors and their capacity as a group even after their defeat in the war. Therefore, the barracks were filled with writing, and the words included in the bulletins were also readable for illiterate people-since the works were tangible and visual. It was precisely that presence-the "graphic occupation" of the camp—that was the greatest

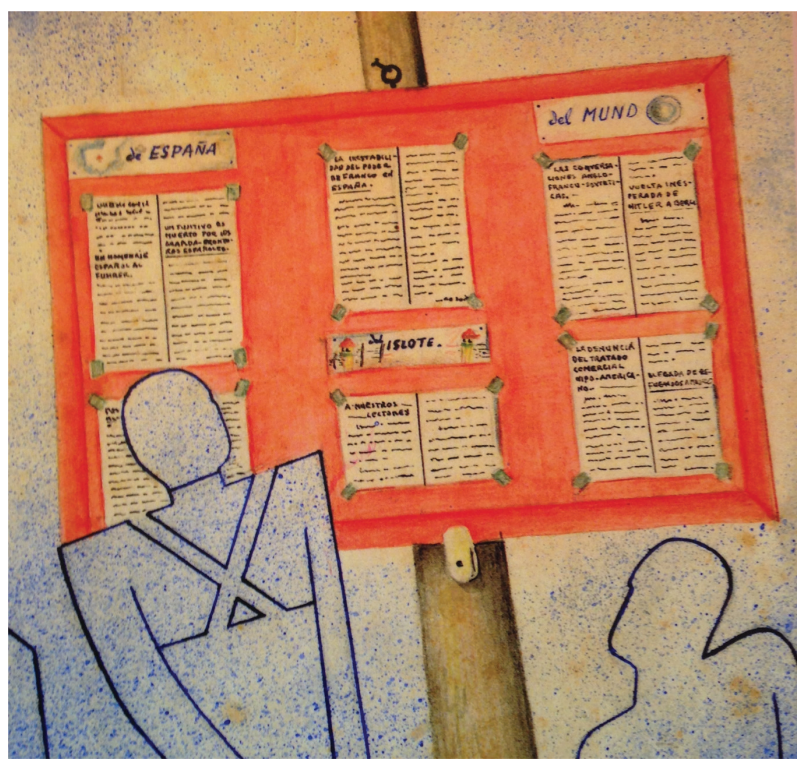

Figure 5 Luis Bonet López's design (Journal Mural). Unknown camp and date. Source: Reproduced in V. Moulinié, 2009 (couverture). 
achievement of the refugees. ${ }^{40}$ They used this exposition to appropriate a space that did not belong to them, and therefore these exhibitions contributed to their challenging of power and established norms, as well as to their union as a community.

This "no-where place" was full of content at the end, and it was constantly reordering and re-structuring itself. ${ }^{41}$ According to Francie Cate-Arries, the internment camps became a place of resistance and subversion in which the exiles were capable of elaborate representations of discourse and, by doing so, they started to write a new national history as they re-organized politically. ${ }^{42}$ Sheets of paper, pencils, posters... all of these were means for the exiles to conquer an empty space, and thereby the refugees were able to recreate some personality and identity that had been taken from them. As has been shown by various authors, culture was, all in all, the "umbilical cord" that kept them close to the Spanish Republic. ${ }^{43}$ Writing was the indispensable tool for the refugees to survive and resist, at the same time that they had to bring cohesion in their attempt to build a new community.

\section{ACKNOWLEDGMENT}

This article is part of the Research Project "Scripta in itinere". Discourses, Forms and Appropriations of Written Culture in Public Spaces from the Early Modern Era to the Present (Ref. HAR2014-51883-P), Ministry of Economy and Competitiveness (Spain). I thank Pedro A. Aguilera Mellado and Borja Montero Pérez for their work to translate this paper.

\section{ABOUT THE AUTHOR}

Guadalupe Adámez Castro has a Doctor's degree in History by Universidad de Alcalá de Henares (UAH), where she is currently teaching under a postdoctoral contract (Programa Talento-CAM). She is an active member in Seminario Interdisciplinar de Estudios sobre Cultura Escrita (SIECE) and in the research group LEA (Lectura, Escritura y Alfabetización). Her doctoral dissertation was awarded in the first edition of the Premio Nacional de Tesis Doctorales sobre Movimientos Migratorios en el mundo contemporáneo (CEME-UNED/Dirección General de Migraciones del MEYSS, 2017), as well as in the seventeenth edition of the Premios a Tesis Doctorales of the Sociedad de Condueños of UAH (Philosophed and Letters category). Based in this dissertation, she has published the book Gritos de papel. Las cartas de súplica del exilio español (1936-1945) (Comares, 2017). She has enjoyed a FPU grant in Universidad de Alcalá and been researcher in the ERC Project "Post Scriptum: A Digital Archive of Ordinary Writings" (Universidad de Lisboa) and fellow researcher Juan de la Cierva in Universidad de Salamanca. 
Her study is focused on the ordinary writing during the Exile of Spanish Republicans, mainly about the letters of pleading and request sent by the refugees to several Aid organizations supported by the Republican funds. Furthermore, she works on the personal writing produced in the refugee camps in the French southwest (1939-1945). She has participated in different Conferences and Scientific National meetings (Universidad del País Vasco, Universidad Complutense de Madrid, Universidad de Granada, Universidad de Alcalá, Universidad de Salamanca, etc.) as well as International (Università degli Studi di Macerata, Macerata, Italy; Ateneo español de México, México D.F.; Universidad Autónoma del estado de Morelos, Cuernavaca, Mexico; Université Paris 8, Paris, France; Remarque Institute, New York University, New York, USA). She has also made research stays in Mexico, United States, France and Italy.

\section{ENDNOTES}

1 Beevor, Antony. La guerra civil española. Barcelona: Crítica, 2005 (573).

2 Mistral, Silvia. Éxodo. Diario de una refugiada española (edited by José F. Colmeiro). Barcelona: Icaria Editorial, 2008 (73).

3 For further information about differences between internment and concentration camps, see Kotek, Joël and Rigoulot, Pierre. Los campos de la muerte. Cien años de deportación y exterminio. Barcelona: Salvat Contemporánea, 2001 (Kotek, Joël and Rigoulot, Pierre. Le siècle des camps. Détention, concentration, extermination. Cent ans de mal radical. París: Lattès, 2000).

4 About the different measures set by French Government to get out of the camps, see Dreyfus-Armand, Geneviève. El exilio de los republicanos españoles en Francia. De la Guerra Civil a la muerte de Franco. Barcelona: Crítica, 2000 (71-80); Alted Vigil, Alicia. La voz de los vencidos. El exilio republicano de 1939. Madrid: Aguilar, 2005 (73-90). About re-emigrations, see Rubio, Javier. La emigración de la Guerra Civil de 1936-1939. Madrid: Editorial San Martín, 1977, Vol. I (115-208).

5 Gaspar Celaya, Diego. La guerra continúa. Voluntarios españoles al servicio de la Francia libre (1940-1945). Madrid: Marcial Pons, 2016.

6 Solé, Felip and Tuban, Grégory. Camp d'Argelers, 1939-1942. Barcelona: Cossetània, 2011 (128-153).

7 Kotek and Rigoulot, 2001 (289-290).

8 Rubio, "Política francesa de acogida. Los campos de internamiento". In Cuesta and Bermejo (coord.), Emigración y exilio. Españoles en Francia, 1936-1946. Madrid, 1996, 87-108 (102).

9 For further information about internment camps, see Rafaneau-Boj, Marie-Claude. Los campos de concentración de los refugiados españoles en Francia (1939-1945). Barcelona: Ediciones Omega 1995; Dreyfus-Armand, Geneviève and Temime, Emile. Les Camps sur la plage, un exil espagnol. París: Éditions Autrement, 1995; Peschanski, Denis. La France des camps. Linternement, 1938-1946. París: Gallimard, 2002.

10 Marcó Gil, Jaime. De punta de N’Amer a St. Cyprien. La olimpiada del 18 de julio de 1936. Palma de Mallorca: Edición del autor, 1990 (128).

11 Espinar, Jaime. Argelès-sur-mer. Campo de concentración para españoles. Caracas: Élite, 1940 (79). 
12 Bartoli, Josep and Molins I Fabrega, Narcís. Campos de concentración (1939-194...). Mexico D.F.: Ediciones Iberia, 1944 (43).

13 Leon Grinberg and Rebeca Grinberg affirm that the feeling of loss of identity emerges when the link of spatial, temporal and social integration has been broken. Grinberg, Leon and Grinberg, Rebeca. Psicoanálisis de la migración y del exilio. Madrid: Alianza Editorial, 1989.

14 About WWII see among others Franchini, "Leer y escribir en los lager. Modalidades de resistencia de los prisioneros italianos en Alemania durante la segunda guerra mundial”. In Castillo Gómez and Sierra Blas (eds.), Letras bajo sospecha. Escritura y lectura en centros de internamiento. Gijón, 2005, 201-216; Vania Waxman, Zoë. Writing the Holocaust. Identity, Testimony, Representation. Oxford: Oxford University Press, 2006. On Franco's dictatorship, see Castillo Gómez, "Escribir para no morir. La escritura en las cárceles franquistas". In Castillo Gómez and Montero (coord.), Franquismo y memoria popular. Escritura, voces y representaciones. Madrid, 2006, 17-53; Sierra Blas, "Del papel al muro. Una aproximación al universo gráfico carcelario de la guerra y la posguerra españolas". In Ortíz (coord.), Lugares de represión. Paisajes de la memoria. Aspectos materiales y simbólicos de la cárcel de Carabanchel. Madrid, 2013, 327-366 and by the same author, Letras presas. La correspondencia carcelaria en la Guerra Civil y el Franquismo. Madrid: Marcial Pons, 2016.

15 Petrucci, Armando. Scrivere lettere. Una storia plurimillenaria. Roma-Bari: Laterza, 2008 (148).

16 About the importance of the correspondance and the mail systems inside the camps, see García Sánchez, "La correspondencia de los españoles en Francia (1936-1946)". In Cuesta and Bermejo, 1996, 330-343; Adámez Castro, "La escritura necesaria: el uso de la correspondencia en las memorias y autobiografías de los exiliados españoles”. In Ibarra, Alejandra (ed.), No es país para jóvenes. III Encuentro de Jóvenes Investigadores de la Asociación de Historia Contemporánea. Vitoria: Universidad del País Vasco, 2012, 1-22; and Adámez Castro, "Cartas entre alambradas. La organización del correo en los campos de refugiados españoles durante el primer exilio (1939-1945)”. In Castillo Gómez y Sierra Blas (dirs.), Cartas-lettres-lettere. Discursos, prácticas y representaciones epistolares (siglos XIVXX). Alcalá de Henares (Madrid): Universidad de Alcalá, 2014 (499-515).

17 Sending of correspondence forms between April $15^{\text {th }}$ and June $15^{\text {th }} 1939$. Centro Documental de la Memoria Histórica (CDMH), Salamanca, Fondo del Comité de la Cruz Roja Internacional, C-ESCI, exp. 5, doc. 15.

18 About request letters, see Adámez Castro, Guadalupe. Gritos de papel. Las cartas de súplica del exilio español (1936-1945). Granada: Comares, 2017.

19 del Rosal, Amaro. Historia de la UGT de España en la emigración. Barcelona: Grijalbo, 1978, Vol. I (70).

20 For further information, see Sánchez Zapatero, Javier. Escribir el horror. Literatura y campos de concentración. Barcelona: Montesinos, 2010 and Simón, Paula. Exilio y memoria en los testimonios sobre los campos de concentración y franceses. La escritura de las alambradas. Vigo: Academia del Hispanismo, 2012.

21 Reverter, Elisa. Dones a l'infern. Barcelona: Columna, 1995 (9).

22 Villegas, Jean-Claude (coord.). Plages d'exil. Les camps de réfugiés espagnols en France, 1939. Nanterre: BDIC, 1989; and Villegas, Jean-Claude. Desde el Rosellón: Écrits d'exil. Barraca et Desde el Rosellon. Albums d'art de littérature à Argelès-sur-Mer, en 1939, par un groupe de républicans espagnols réfugiés. Sète: NPL Éditions, 2008.

23 Cruz, J. Ignacio, "Los barracones de la cultura. Noticias sobre las actividades educativas de los exiliados españoles en los campos de refugiados”. Clío [26], 2002, without paging.

24 Report by Amparo Ruiz, member of FETE, about cultural activities inside the camps, sent to Amaro de Rosal (UGT Delegation in París), July 8th 1939. AARD-FPI, box 270, folder 2 . 
25 Boletín de los estudiantes, 10, Argelès-sur-Mer (9). Included in Villegas, 1989.

26 Salaun, "Education et culture dans les camps de réfugiés". In Villegas, 1989, 117-124 (119).

27 Villegas, 1989 (133-140).

28 Sierra Blas, "La información como resistencia. Periódicos manuscritos en las cárceles de Franco". In Desvois, J. M. (ed.). Prensa, impresos, lectura en el mundo hispánico contemporáneo. Bordeaux, 2005, 437-462.

29 All of them conserved in ALBA/Moscow Microfilm, Opis 4, f. 16-29. I thank Diego Gaspar Celaya for showing me this documentation.

30 Unione. Giornale Murale, Saint-Cyprien, ALBA/Moscow Microfilm, Opis 4, f. 16-29.

31 Godicheau, François, "Periódicos clandestinos anarquistas en 1937-1938: ¿las voces de la base militante". Ayer [55], 2004, 175-205 (200).

32 Villegas, 2008.

33 Boletín de los Profesionales de la Enseñanza, 1, Argelès-sur-Mer (1). Included in Villegas, 1989

34 Exilio, 1, Bram (3). Included in http://www.exiliadosrepublicanos.info/es/testimonioscampos/revista-exilio.

35 Morera, Arturo. Remembranza de los años pretéritos [Unpublished Memoir, Arxiu de la Memoria Popular. La Roca del Vallés, Barcelona, 2008] (165).

36 Ferran de Pol, Lluis. Campo de concentración (1939). Barcelona: Publicacions de l'Abadia de Montserrat/Ajuntament d'Arenys de Mar, 2003 (61).

37 Laharie, Claude. Le camp de Gurs. 1939-1945. Un aspect méconnu de l'histoire de Vichy. Biarritz : Société Atlantique d'Impression, 1993 (95-96).

38 Chartier, Roger. El orden de los libros. Lectores, autores, bibliotecas en Europa entre los siglos XIV y XVIII. Barcelona: Ariel, 1994 (31).

39 de Hoyos Puente, Jorge. La utopía del regreso. Proyectos de Estado y sueños de nación en el exilio republicano en México. Santander: Universidad de Cantabria, 2012 (121-170).

40 For the concept of the "graphic occupation" I follow Petrucci, Armando. Public Lettering. Script, Power and Culture. Chicago: University of Chicago Press, 1993 (118-119).

41 Moulinié, Véronique. La Retirada. Mots et images d'un exode. Perpignan: Garae Hésiode, 2009 (119).

42 Cate-Arries, Francie. Culturas del exilio español entre las alambradas. Literatura y memoria de los campos de concentración en Francia, 1939-1945. Barcelona: Anthropos, 2014 (23).

43 Boix, "La notion de patrie dans le discours des réfugiés espagnols des camps d'Argelès et de Saint-Cyprien”. In Villegas, 1989, 125-132 (130). 